\title{
EFEKTIVITAS PEMBELAJARAN STUDENT TEAM ACHIEVEMENT DIVISION DALAM MENINGKATKAN \\ HASIL BELAJAR PESERTA DIDIK \\ DI SMK NEGERI 1 PAREPARE
}

\author{
Muhammad Jufri \\ SMKN 1 Parepare \\ Email: muhammad.jufri@rocketmail.com
}

\begin{abstract}
This article discusses about the Effectiveness of Learning Student Team Achievement Division in Improving Student Learning Outcomes in SMK Negeri 1 Parpare. The importance of this research is done because of the essence of learning trough student team achievement division and the implementation steps have not been done on the research object. The level of learning decided of student still need to be maximized to achieve the minimum completion criteria established by the school. The objective of the research is to know the form of implementation and effectiveness of learning trough Student Team Achievement Division in improving the outcomes (result) of learning Islamic Religion Education for the eleventh grade on SMK Negeri 1 Parepare.The research setting used in this research is a classroom action research which was conducted cyclically with experimental approach. The subjects of this research are the eleventh grade (class) on SMK Negeri 1 Parepare and the numbers of the subjects are 25 student. The method of data collection as research instrument is test, participant observation sheet, and documentation, the data analysis technique used frequency distribution analysis.The research result found that: (1) the implementation of learning student team achievement division has a positive impact on the cooperation among student which is shown by the responsibility of the students in the group, in the learning process by using the learning student team achievement division that is done in cyclical technique student activeness has improved better than using lecturing method. (2) The results of learning Islamic Religion Education have been increased after using the learning student team achievement division. This can be shown from the average score of the students test, the average of pre test is 70,4; in the first cycle the score average of the post test increased up to 85,80; and in the final test (post test) of the second cycle the score average increased up to 96,60. As cocnclusion, Student Team Achievement Division (STAD) as learning strategy is
\end{abstract}


effective to improve the students learning outcomes of the eleventh grade of SMK Negeri 1 Parepare.

Keywords: STAD, Learning Outcome

\begin{abstract}
ABSTRAK
Artikel ini membahas tentang Efektivitas Pembelajaran Student Team Achievment Division dalam Meningkatkan Hasil Belajar Peserta Didik di SMK Negeri 1 Parepare. Pentingnya penelitian ini dilakukan karena esensi pembelajaran Student Team Achievement Division dan langkah-langkah penerapannya belum dilakukan pada objek penelitian. Demikian pula pada tingkat hasil belajar peserta didik masih perlu dimaksimalkan untuk mencapai kriteria ketuntasan minimal yang ditetapkan oleh sekolah. Tujuan penelitian adalah untuk mengetahui bentuk pelaksanaan dan efektivitas pembelajaran Student Team Achievment Division dalam meningkatkan hasil belajar Pendidikan Agama Islam kelas XI di SMK Negeri 1 Parepare.Setting penelitian yang pergunakan dalam penelitian ini adalah penelitian tindakan kelas yang dilakukan secara bersiklus dengan pendekatan eksperimen. Subjek penelitian ini adalah peserta didik kelas XI di SMK Negeri 1 Parepare sebanyak 25 orang. Adapun metode pengumpulan data sebagai instrumen penelitian adalah test, lembar observasi berpartisipatif, dan dokumentasi; sedangkan teknik analisis datanya mempergunakan analisis distribusi frekuensi.Hasil penelitian ditemukan: (1) Pelaksanaan pembelajaran Student Teams Achievement Divisions memiliki dampak positif terhadap kerjasama antar siswa yang ditunjukkan oleh tanggung jawab siswa dalam kelompok. Dalam proses pembelajaran dengan menggunakan pembelajaran Student Team Achievment Division yang dilakukan secara bersiklus, keaktifan siswa mengalami peningkatan yang lebih baik dibandingkan menggunakan metode ceramah. (2) Hasil belajar Pendidikan Agama Islam siswa mengalami peningkatan setelah menggunakan pembelajaran Student Team Achievment Division. Hal ini dapat ditunjukkan dari nilai rata-rata test siswa, yaitu rata-rata nilai test awal 70,4; pada siklus I nilai rata-rata test akhir meningkat menjadi 85,80; dan pada test akhir siklus II nilai rata-ratanya meningkat menjadi 96,60. Dengan demikian, pembelajaran Student Team Achievment Division efektif dalam meningkatkan hasil belajar siswa khususnya di kelas XI SMK Negeri 1 Parepare.Pembelajaran Student Team Achievment Division efektif dalam meningkatkan hasil pembelajaran Pendidikan Agama Islam di SMK Negeri
\end{abstract}


1 Parepare. Hasil penelitian ini dapat dijadikan sebagai bahan masukan dan khasanah intelektual dalam pendekatan pembelajaran.

Kata Kunci: STAD, Hasil Belajar

\section{PENDAHULUAN}

\section{Latar Belakang}

Efektivitas pencapaian tujuan instruksional dalam bentuk peningkatan hasil pembelajaran peserta didik dapat dipengaruhi oleh dua faktor, yaitu faktor instrumental input dan environmental input. Pada faktor instrumental input dibagi atas faktor kurikulum, pendidik, model dan strategi pembelajaran, materi, waktu, dan biaya pendidikan. Sedangkan pada faktor environmental input adalah terdiri atas faktor lingkungan pendidikan, baik lingkungan keluarga, masyarakat, lingkungan sosial budaya, keamanan, politik dan lingkungan keagmaan.

Dalam penelitian ini, berfokus pada faktor instrumental input yaitu faktor pendidik dan model pembelajarannya dalam meningkatkan hasil belajar peserta didik. Penelitian ini sangat penting dilakukan, obeservasi awal penulis menunjukkan bahwa kurangnya penerapan model pembelajaran Student Team Achievment Division pada masing-masing sekolah di tingkat sekolah menengah dan sederajat sebagai salah satu modus ketidakefektifan proses pembelajaran di kelas. Sementara salah satu asumsi ideal tentang meningkatnya hasil belajar peserta didik adalah dengan penerapan model pembelajaran kooperatif. Dengan demikian, model pembelajaran Student Team Achievment Division penting untuk diteliti.

Fenomena strategi pembelajaran yang umum dipraktekkan di masingmasing sekolah khususnya pada objek penelitian ini adalah strategi dan konsep lama yaitu ceramah, tanya jawab, penugasan, resitasi, demonstrasi, dan lain-lain. Dalam proses pembelajaran mencakup komponen pendekatan dan berbagai metode dan model pembelajaran yang dikembangkan, seperti model pembelajaran contekstual learning, e-learning, cooperative larning dan sebagainya. Semua model pembelajaran dari berbagai konsep, teori, dan aplikasinya tentu bertujuan untuk meningkatkan hasil belajar peserta didik. Tugas peneliti adalah ingin menguji coba efektivitas model pembelajaran kooperatif tipe Student Team Achievment Division dalam bentuk penelitian tindakan kelas. 


\section{Rumusan Masalah}

Berdasarkan latar belakang dan variabel-bariabel penelitian, maka yang menjadi pokok masalah dalam penelitian ini adalah bagaimana efektivitas pembelajaran Student Team Achievment Division dalam peningkatan hasil belajar Pendidikan Agama Islam peserta didik kelas XI di SMK Negeri 1 Parepare. Pokok permasalahan tersebut dijabarkan dalam beberapa sub masalah sebagai berikut:

1. Bagaimana tahapan pelaksanaan pembelajaran Student Team Achievment Division kelas XI di SMK Negeri 1 Parepare?

2. Bagaimana efektivitas pembelajaran Student Team Achievment Division dalam peningkatan hasil belajar Pendidikan Agama Islam peserta didik kelas XI di SMK Negeri 1 Parepare?

\section{a) Sejarah dan Pengertian Pembelajaran Kooperatif}

Secara umum model pembelajaran cooperative learning adalah model pembelajaran yang mengutamakan kerjasama yang saling menguntungkan, jauh dari segala unsur perbedaan peserta didik baik agama, suku, ras yang dapat menimbulkan konflik.

Model pembelajaran ini dipopulerkan sekitar tahun 1950-an adalah merupakan salah satu solusi jalan keluar digunakan Amerika Serikat pada tahun 1954 atas terjadinya konflik antar ras kulit putih dan kulit hitam, antara hispanik (Latin Spanyol dan Portugis). Konsep pembelajaran ini pada masa itu adalah pembelajaran yang berazaskan kerjasama antara rasial untuk menciptakan kondisi pembelajaran yang saling menguntungkan antara ras dan suku bangsa yang berbeda di Amerika. ${ }^{1}$

Pencetus ide cooperative learning adalah John Dewey pada tahun 1916 dalam bukunya yang berjudul: Democracy and Education kemudian pada kurun waktu 1954-1960 Herbert Thelen mengembangkan prosedurprosedur yang lebih teliti untuk membantu peserta didik bekerja dalam kelompok. $^{2}$

\footnotetext{
${ }^{1}$ Arendsdalam www//Yosiabdiantindoan.blogspot.com, Sejarah Cooperative Learning dengan Concept Sentence 12 November 2012 dandiunggahpadahariAhad, 17 Oktober 2016: 07:00.

${ }^{2}$ Arendsdalam www//Yosiabdiantindoan.blogspot.com, Sejarah Cooperative Learning dengan Concept Sentence 12 November 2012 dandiunggahpadahariAhad, 17 Oktober 2016: 07:00.
} 


\section{b) Pembelajaran Student Team Achievment Division}

Student Team Achievement Division merupakan salah satu model atau pendekatan dalam pembelajaran koopertif yang sederhana dan baik untuk guru yang baru menggunakan pendekatan kooperatif dalam kelas. ${ }^{3}$ Model ini dikembangkan oleh Robert Slavin dan teman-temannya di Unversitas John Hopkin yang mengacu pada belajar kelompok siswa. ${ }^{4}$

Robert Slavin yang dikutip oleh Trianto menyatakan bahwa pada Student Team Achievement Division peserta didik ditempatkan dalam tim belajar beranggotakan 4-6 orang yang merupakan campuran menurut tingkat prestasi, jenis kelamin, dan suku.

Fase model pembelajaran Student Team Achievement Division, yaitu Fase 1: Guru presentasi, memberikan materi yang akan dipelajari secara garis besar dan prosedur kegiatan, juga tata cara kerja kelompok. Fase 2: Guru membentuk kelompok berdasarkan kemampuan, jenis kelamin, ras, suku, jumlah antara 3-5 peserta didik. Fase 3: peserta didik bekerja dalam kelompok, peserta didik belajar bersama, diskusi atau mengerjakan tugas yang diberikan guru sesuai LKS. Fase 4: Scafolding, guru memberikan bimbingan. Fase 5: Quizzes, guru mengadakan kuis secara individu, hasil nilai dikumpulkan, dirata-rata dalam kelompok, selisih skor awal (base score) individu dengan skor hasil kuis (skor perkembangan). Fase 6: Penghargaan kelompok, berdasarkan skor perhitungan yang diperoleh anggota, dirata-rata, hasilnya dijumlah dengan nilai kelompok. Fase 7: Evaluasi yang dilakukan oleh guru. ${ }^{5}$

\section{c) Hasil Belajar Peserta Didik}

Hasil belajar adalah pola-pola perbuatan, nilai-nilai, pengertianpengertian, sikap-sikap, apresiasi dan keterampilan. ${ }^{6}$ Menurut Mulyana Abdurrahman, prestasi belajar juga disebut hasil belajar adalah kemampuan anak setelah melalui kegiatan belajar. ${ }^{7}$ Hasil belajar merupakan hasil dari

\footnotetext{
${ }^{3}$ Agus N Cahyo, Panduan Aplikasi Teori-teori Belajar Mengajar Teraktual dan Terpopuler (Jogyakarta: DIVA Press, 2013), h.228.

${ }^{4}$ Ismail Sukardi, Model-Model Pembelajaran Modern: Bekal Untuk Guru Profesinal (Jakarta: Tunas Gemilang Press, 2013), h. 146.

${ }^{5}$ Hendygo, PerbandinganPenerapanPembelajaranhttp://hendygo.blogspot. com, 2009, diaksespada 13 Aprili 2016 pukul 19.10 WIB.

${ }^{6}$ Agus Suprijono, Cooperative Learnning Teori \& Apllikasi Paikem (Yogyakarta: Pustaka Pelajar, 2010), h. 5.

${ }^{7}$ Mulyana Abdurrahman, PendidikanBagiAnakBerkesulitanBelajar (Jakarta: PT. RinekaCipta, 2003), h. 37.
} 
suatu interaksi tindak belajar dan tindak mengajar. ${ }^{8}$ Bukti bahwa seseorang telah mengalami belajar ialah terjadinya perubahan tingkah laku pada seseorang tersebut, misalnya dari tidak tahu menjadi tahu dan dari tidak mengerti menjadi mengerti. ${ }^{9}$

Hasil belajar adalah sesuatu yang di peroleh dalam usaha sadar yang dilakukan oleh seseorang atau kelompok dalam pembelajaran. ${ }^{10}$ Hasil belajar peserta didik pada hakikatnya adalah perubahan tingkah laku dan sebagai umpan balik dalam upaya memperbaiki proses belajar mengajar. Tingkah laku sebagai hasil belajar dalam pengertian luas mencakup bidang kognitif, afektif dan psikomotorik. Hal ini dapat dipahami bahwa hasil belajar adalah tindakan yang dilakukan secara sadar sehingga terjadi perubahan atas tidakan sadar tersebut. Perubahan itu dapat berupa pengetahuan, sikap, dan keterampilan yang dialami oleh peserta didik.

\section{Kerangka Konseptual Penelitian}

Kerangka pikir dalam penelitian tindakan kelas merujuk pada teori yang menyatakan bahwa pembelajaran Student Team Achievement Division adalah suatu pembelajaran dengan peserta didik ditempatkan dalam tim belajar beranggotakan 4-6 orang yang merupakan campuran menurut tingkat prestasi, jenis kelamin, dan suku. Guru menyajikan pelajaran, dan kemudian peserta didik bekerja dalam tim mereka memastikan bahwa seluruh anggota tim telah menguasai pelajaran tersebut. Kemudian, seluruh peserta didik diberikan test tentang materi tersebut, pada saat test ini mereka tidak diperbolehkan saling membantu.

Hasil test yang dilaksanakan mulai test awal sampai siklus satu dan seterusnya diperoleh prestasi belajar peserta didik. Hasil belajar inilah yang akan dianalisis untuk mendapatkan nilai rata-rata dan peningkatannya. Proses pelaksanaan Penelitian Tindakan Kelas dalam menerapkan pembelajaran Student Team Achievement Division dapat digambarkan dalam gambar sebagai berikut:

\footnotetext{
${ }^{8}$ Dimyati, Mudjiono, Belajar dan Pembelajaran (Jakarta: PT. Rineka Cipta, 2009), h. 3.

${ }^{9}$ OemarHamalik, Proses BelajarMengajar(Jakarta: BumiAksara, 2007), h. 30.

${ }^{10}$ Dalyono, Psikologi Pendidikan (Jakarta: Rineka Cipta, 2005), h. 55.
} 


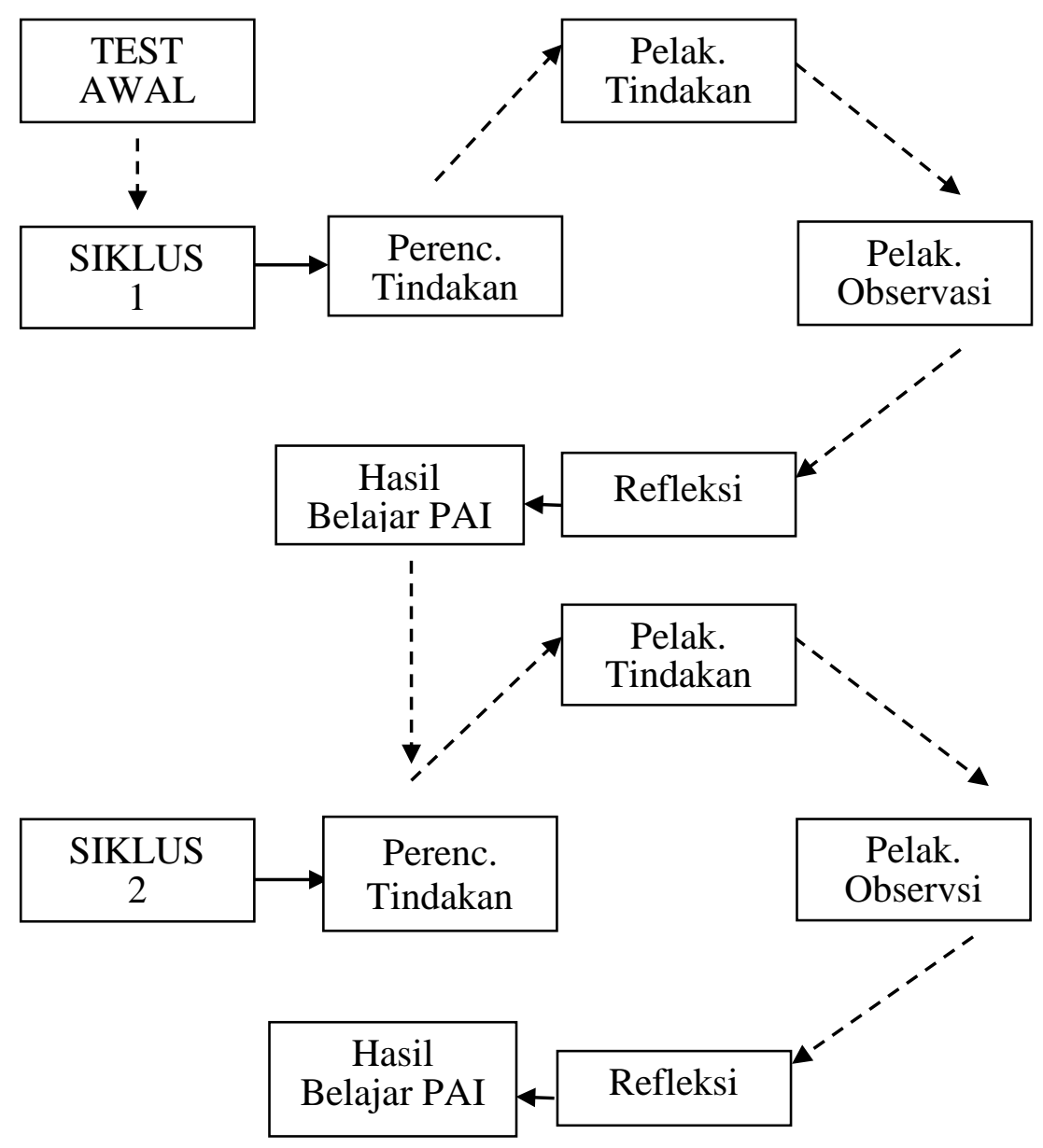

Gambar: Siklus Penelitian Tindakan Kelas oleh Kemmis dan MC. Taggar, 1990. ${ }^{11}$

\section{Hipotesis Tindakan}

Hipotesis tindakan dalam penelitian ini adalah:

1. Pelaksanaan model pembelajaran Student Team Achievement Division kelas XI di SMK Negeri 1 Parepare dilakukan secara bersiklus. Pada setiap siklus dilaksanakan melalui empat tahapan, yaitu tahap perencanaan, observasi, tindakan, dan refleksi. Tahapan inilah yang dijadikan proses pelaksanaan penelitian tindakan kelas.

\footnotetext{
${ }^{11}$ Agus Purwatjahyono, Penelitian Tindakan Kelas (Bandung: Retika Aditama, 2012), h. 59.
} 
2. Model pembelajaran Student Team Achievement Division efektif dalam peningkatan hasil belajar Pendidikan Agama Islam kelas XI di SMK Negeri 1 Parepare. Hal ini dapat dibuktikan terjadinya peningkatan hasil belajar pada setiap test siklus, yaitu pelaksanaan test awal, test siklus 1 , dan test siklus 2 .

\section{Metode Penelitian}

\section{Setting Penelitian}

Penelitian ini adalah penelitian tindakan kelas (classroom action research). Penelitian tindakan kelas bertujuan untuk meningkatkan kualitas proses, pendekatan strategi pembelajaran dan hasil belajar peserta didik. Penelitian ini meliputi langkah-langkah yaitu tahapan perencanaan (planning), pelaksanaan tindakan (acting), observasi (observing), dan refleksi (reflecting). Penelitian tindakan kelas ini dilakukan secara bersiklus, yaitu siklus satu dan siklus dua. Dalam satu siklus dilakukan tiga kali pertemua proses pembelajaran ditambah satu kali test, demikian pula pada siklus kedua.

\section{Tempat dan Waktu Penelitian}

Letak geografis SMK Negeri 1 Parepare berada di Jalan poros ParepareMakassar Jalan Bau Massepe No.34 RT 1 / RW 6, Kelurahan Lumpue,Kecamatan Bacukiki Barat Kota Parepare, Provinsi Sulawesi Selatan. SMK Negeri 1 Parepare berdiri pada tanggal 07 Pebruari 1986. SMK Negeri 1 Parepare berada di daerah pinggiran Kota Parepare yang merupakan salah satu sekolah unggulan pada sekolah lanjutan tingkat menengah dengan luas lahan sekitar $2000 \mathrm{~m}^{2}$. Pos: 91123, nomortelepon dan fax (0421) 3310382, Email: smkn1-pare@yahoo.com, website: http//smkn1pare.sch.id.Nomor Statistik Sekolah: 201196102 001, NPSN: 40307697, jenjang akreditasi B sertifikasi ISO 9001 2008, tahun didirikan: 1996, SK pendirianNomor: 23532-58tanggal 07 Februari 1996, kepemilikan tanah: pemerintah daerah, status tanah: hak pakai dinas, luas tanah: $2000 \mathrm{~m}^{2}$. NPWP Nomor: 000183632802000, Nomor Rekening Bank Rakyat Inodonesia cabang Parepare: 006401000545301, daya listrik PLN: 43600 kwh dengan akses internet smartfren dan telkom speedy.

Posisi letak geografis SMK Negeri 1 Parepare berada pada lintang selatan-utara 4.0637 dan bujur timur-barat 119.6233 sebelah barat adalah 
jalan poros Parepare-Makassar, sebelah selatan dan utara perkampungan penduduk Parepare dan sebelah timur daerah pegunungan.

\section{Subjek Penelitian}

Fokus penelitian ini diarahkan pada pelaksanaan model pembelajaran Student Team Achievment Devision dalam meningkatkan hasil belajar Pendidikan Agama Islam peserta didik di kelas XI pada SMK Negeri 1 Parepare. Jadi, subjek penelitian ini adalah peserta didik kelas XI di SMK Negeri 1 Parepare sebanyak 25 orang (satu kelas).

\section{Instrumen Penelitian}

Untuk memperoleh data tentang prestasi belajar peserta didik, peneliti menggunakan instrumen pengumpulan data. Alat pengumpulan data tersebut adalah tes dan lembar observasi. Observasi digunakan untuk mengumpulkan data tentang aktivitas guru dan peserta didik selama proses pembelajaran berlangsung.

Tes dipergunakan untuk menentukan tingkat prestasi belajar peserta didik pada setiap siklus. Peningkatan prestasi belajar ini dianalisis berdasarkan perbandingan antara pencapaian tes awal dengan siklus satu dan siklus satu dibandingkan dengan siklus dua dan seterusnya. Penerapan siklus ini dilakukan maksimal tiga siklus yang berarti test siklus juga dilakukan mengikuti siklusnya plus test siklus awal.

\section{Teknik Analisis Data}

Pengumpulan data yang diperoleh dari hasil penelitian melalui tes hasil belajar dan lembar observasi selanjutnya dianalisis melalui lembar aktivitas peserta didik. Test hasil belajar dianalisis dengan menggunakan statistik deskriptif untuk menghitung mean, median, modus, nilai maksimun dan nilai minimum.

Dalam menetapkan tingkat penguasaan materi pembelajaran peserta didik versi Departemen Pendidikan dan Kebudayaan yang dikutif oleh Buhaerah adalah teknik kategorisasi skala lima yaitu:

Kemampuan 00\% - 34\% atau 00 - 34 dikategorikan sangat rendah

Kemampuan 35\% - 54\% atau 35 - 54 dikategorikan rendah

Kemampuan $55 \%-64 \%$ atau $55-64$ dikategorikan sedang

Kemampuan $65 \%$ - 84\% atau $65-84$ dikategorikan tinggi 
Kemampuan $85 \%$ - 100\% atau 85 - 100 dikategorikan sangat tinggi. ${ }^{12}$

Pemberian penghargaan kelompok dilakukan berdasarkan nilai test akhir siklus sebagai acuan. Point peningkatan individual dalam kelompok yang dibentuk dikumpulkan berdasarkan skor test dengan berpatokan pada:

1. Lebih dari 10 point di bawah skor awal sebanyak 0 point

2. 10 poin di bawah sampai 1 point di bawah skor awal: 10 point

3. Skor awal sampai 10 point di atas skor awal: 20 point

4. Lebih dari 10 point di atas skor awal: 30 point

5. Nilai sempurna tanpa memperhatikan skor awal: 30 point. $^{13}$

Pemberian penghargaan kelompok diberikan sesuai rata-rata kelompok dengan kriteria yang telah ditentukan yaitu:
1) $0 \leq<x \leq 5$
: Kurang Baik
2) $5 \leq x \leq 15$
: Baik
3) $15 \leq x \leq 25$
: Hebat
4) $25 \leq x \leq 30$
: Super. ${ }^{14}$

\section{PEMBAHASAN}

\section{Tahapan Pelaksanaan Pembelajaran Student Team Achievment Division}

Tahapan siklus yang ditempuh dalam pembelajaran Student Team Achievment Division, yaitu:

1. Peserta didik diberikan test awal dan diperoleh skor awal.

2. Peserta didik dibagi dalam kelompok kecil 4-6 secara heterogen menurut prestasi, jenis kelamin, ras, dan suku.

3. Guru menyampaikan tujuan, menyajikan bahan pelajaran, membimbing kelompok, dan memotivasi peserta didik.

4. Peserta didik diberi test tentang materi yang telah diajarkan.

5. Memberikan penghargaan.

Langkah dalam model pembelajaran Student Team Achievement Devison tersebut dapat memberikan pemahaman bahwa peranan guru sangat penting untuk mengarahkan dan membimbing peserta didik, memberikan garis besar dan prosedur kegiatan, juga tata cara kerja kelompok yang akan

12 Buhaerah, Pengembangan Perangkat Pembelajaran Berdasarkan Masalah pada Materi Statistika (Makasar: UNM, 2009),h. 106.

${ }_{13}$ Buhaerah, Pengembangan Perangkat Pembelajaran Berdasarkan Masalah pada Materi Statistika (Makasar: UNM, 2009),h. 109.

${ }^{14}$ Buhaerah, Pengembangan Perangkat Pembelajaran Berdasarkan Masalah pada Materi Statistika (Makasar: UNM, 2009),h. 110. 
dipelajari. Tentu seorang guru membentuk kelompok, membimbing, mengadakan kuis dan menilai peserta didik. pemberian nilai rata-rata peserta didik dan nilai rata-rata kelompok diperuntukkan untuk menentukan tingkat peningkatan hasil belajar dan memberikan penghargaan kelompok sehingga memungkinkan untuk melakukan reflecting dan membuat suatu kesimpulan hasil pelaksanaan siklus.

Efektivitas Pembelajaran Student Team Achievment Division di SMK Negeri 1 Parepare

Paparan Data Pra Tindakan (Refleksi Awal)

Tabel 1

Nilai Test Awal Siswa

\begin{tabular}{|c|c|c|c|c|c|c|c|c|c|c|c|c|c|c|c|}
\hline \multirow{3}{*}{ No. } & \multirow{3}{*}{$\begin{array}{l}\text { Nama } \\
\text { Siswa }\end{array}$} & \multirow{3}{*}{$\mathrm{L} / \mathrm{P}$} & \multicolumn{10}{|c|}{ NomorSoal dan Bobot Nilai } & \multirow{3}{*}{$\begin{array}{c}\text { Jml } \\
\text { Nilai }\end{array}$} & \multirow{2}{*}{\multicolumn{2}{|c|}{ Ket }} \\
\hline & & & \multirow{2}{*}{$\frac{1}{10}$} & \multirow{2}{*}{$\begin{array}{c}2 \\
10\end{array}$} & \multirow{2}{*}{$\begin{array}{l}3 \\
10\end{array}$} & \multirow{2}{*}{$\begin{array}{c}4 \\
10\end{array}$} & \multirow{2}{*}{\begin{tabular}{|c|}
5 \\
10
\end{tabular}} & \multirow{2}{*}{$\begin{array}{c}6 \\
10\end{array}$} & \multirow{2}{*}{$\begin{array}{c}7 \\
10\end{array}$} & \multirow{2}{*}{$\begin{array}{c}8 \\
10\end{array}$} & \multirow{2}{*}{\begin{tabular}{|c|}
9 \\
10
\end{tabular}} & \multirow{2}{*}{$\begin{array}{l}10 \\
10\end{array}$} & & & \\
\hline & & & & & & & & & & & & & & $\mathrm{T}$ & TT \\
\hline 1. & Fila N. & $\mathrm{P}$ & 10 & 10 & 10 & 10 & 10 & 10 & 10 & 5 & 10 & 5 & 90 & $\mathrm{~T}$ & TT \\
\hline 2. & Fitriani & $\mathrm{P}$ & 10 & 10 & 10 & 10 & - & - & 10 & 10 & - & - & 60 & & TT \\
\hline 3. & Haerul & $\mathrm{L}$ & 10 & - & 10 & 10 & 10 & 10 & 10 & - & 10 & 5 & 85 & $\mathrm{~T}$ & TT \\
\hline 4. & Hasda & $\mathrm{P}$ & 10 & 10 & 10 & 10 & - & 10 & 10 & 10 & 10 & - & 80 & & TT \\
\hline 5. & Hasnia & $\mathrm{P}$ & 10 & - & 10 & 10 & 10 & 10 & 10 & 10 & - & - & 70 & & TT \\
\hline 6. & Hasrina & $\mathrm{P}$ & 10 & 10 & 10 & 10 & 5 & 10 & - & 5 & 10 & - & 70 & & TT \\
\hline 7. & Herlia & $\mathrm{P}$ & 10 & 10 & 10 & 10 & 10 & 10 & - & 10 & - & 5 & 75 & & TT \\
\hline 8. & Haruna & $\mathrm{L}$ & 10 & 10 & 10 & 10 & 10 & 10 & 5 & - & - & - & 65 & & TT \\
\hline 9. & Herlinda & $\mathrm{P}$ & 10 & 10 & 10 & - & 10 & 10 & 10 & 10 & 5 & - & 75 & & TT \\
\hline 10. & Hesti & $\mathrm{P}$ & 10 & 10 & 10 & 10 & 10 & 10 & 5 & - & - & - & 65 & & TT \\
\hline 11. & Ika P. & $\mathrm{P}$ & 10 & 10 & 10 & 10 & 10 & 10 & 10 & - & - & 5 & 75 & & TT \\
\hline 12. & Ilham & $\mathrm{L}$ & 10 & 10 & 10 & 10 & 10 & 10 & 10 & - & - & 10 & 80 & & TT \\
\hline 13. & Indah S. & $\mathrm{P}$ & 10 & 10 & 10 & 10 & 10 & 10 & 10 & 5 & 5 & 5 & 85 & & TT \\
\hline 14. & Iqbal & $\mathrm{L}$ & 10 & 10 & 10 & - & - & 5 & - & - & - & - & 45 & & TT \\
\hline 15. & Irwanti & $\mathrm{P}$ & 10 & - & - & 10 & 10 & 10 & - & - & - & 10 & 50 & & TT \\
\hline 16. & Jabal R. & $\mathrm{L}$ & 10 & 10 & 10 & 10 & 10 & 10 & - & - & 10 & - & 70 & & TT \\
\hline 17. & Jumatan & $\mathrm{P}$ & 10 & 10 & 10 & 10 & 10 & - & 10 & 5 & 10 & - & 75 & & TT \\
\hline 18. & Khusnul & $\mathrm{P}$ & 10 & 10 & 10 & 10 & 10 & 10 & 10 & 5 & - & - & 75 & & TT \\
\hline 19. & Kurniati & $\mathrm{P}$ & 10 & 10 & 10 & 10 & - & - & 10 & 10 & 5 & 5 & 70 & & TT \\
\hline 20. & Leni P. & $\mathrm{P}$ & 10 & 10 & 10 & - & 10 & 10 & 5 & 10 & - & - & 65 & & TT \\
\hline 21. & Lucy N. & $\mathrm{P}$ & 10 & 10 & 10 & 10 & 10 & 10 & 10 & - & - & 5 & 75 & & TT \\
\hline 22. & Lukman & $\mathrm{L}$ & 10 & 10 & - & 10 & - & - & 10 & - & 10 & 10 & 60 & & TT \\
\hline 23. & Magfirah & $\mathrm{P}$ & 10 & 10 & 10 & - & 10 & 10 & - & - & 10 & - & 60 & & TT \\
\hline 24. & Marni S. & $\mathrm{P}$ & 10 & 10 & 5 & 10 & 10 & - & - & - & 10 & - & 55 & & TT \\
\hline 25. & Mira I.P. & $\mathrm{P}$ & 10 & 10 & 10 & 10 & 10 & 5 & 5 & 10 & 10 & 5 & 85 & $\mathrm{~T}$ & \\
\hline & & & & & Jum & & & & & & & & 1760 & 3 & 22 \\
\hline & & & & & Rata- & & & & & & & & 70,4 & $\begin{array}{l}12 \\
\%\end{array}$ & $\begin{array}{l}88 \\
\%\end{array}$ \\
\hline
\end{tabular}




$$
\begin{aligned}
\text { Mean } & =\frac{\sum \mathrm{X}}{\mathrm{N}} \mathrm{X} 100 \\
& =\frac{1760}{25} \mathrm{X} 100=70,4
\end{aligned}
$$

Keterangan : T: Tuntas, $\quad$ TT : Tidak Tuntas

Dapat diketahui bahwa siswa kurang menguasai materi pelajaran. Ini terbukti dengan jumlah nilai rata-rata (mean) test awal sebelum dilakukan tindakan dipereoleh nilai rata-rata siswa sebanyak 70,4. Siswa yang menyelesaikan soal dan tergolong tuntas belajar hanya ada 3 orang siswa dari 25 siswa. Siswa banyak melakukan kesalahan dalam menjawab soal sehingga disimpulkan bahwa siswa belum sepenuhnya mengetahui pokokpokok bahasan Pendidikan Agama Islam.

Proses selanjutnya adalah pembentukan kelompok belajar masingmasing 5 orang dalam satu kelompok. Teknik pembentukan kelompok ini dilakukan berdasarkan hasil test awal dan latar belakang, jenis kelamin, heterogenistas, dan kepandaiannya.

\section{Paparan Data Pelaksanaan Tindakan Siklus I}

Pelaksanaan penelitian tindakan kelas yang dilakukan pada siklus I meliputi empat kegiatan, yaitu kegiatan perencanaan, pelaksanaan tindakan, observasi, dan refleksi yang membentuk suatu siklus.

\section{a. Hasil Observasi}

Pengamatan dilakukan oleh dua pengamat, yaitu ibu Harwiyani sebagai pengamat 1 (teman sejawat guru mata pelajaran Pendidikan Agama Islam) dan bapak Zainal sebagai pengamat 2 (teman sejawat guru mata pelajaran Pendidikan Agama Islam). Pengamat 1 bertugas mengamati semua aktivitas yang dilakukan oleh guru (peneliti) dan pengamat 2 bertugas mengamati semua aktivitas siswa selama proses pembelajaran berlangsung. Pengamatan ini dilakukan sesuai pedoman yang telah disediakan oleh peneliti.

Hasil pengamatan terhadap aktivitas peneliti dapat dilihat pada tabel berikut: 
Tabel 2

Hasil Pengamatan Aktivitas Peneliti/ Guru pada Siklus I

\begin{tabular}{|c|l|c|c|}
\hline \multirow{2}{*}{ Tahap } & \multicolumn{1}{|c|}{ Indikator } & \multicolumn{2}{c|}{ HasilPengamatan } \\
\cline { 3 - 4 } & & Skor & Catatan \\
\hline \multirow{5}{*}{ Awal } & Melakukanaktivitasrutinsehari-hari & 4 & $\mathrm{~B}$ \\
\cline { 2 - 4 } & Menyampaikantujuan & 5 & $\mathrm{~A}$ \\
\cline { 2 - 4 } & $\begin{array}{l}\text { Membangkitkanpengetahuanpersyaratansis } \\
\text { wa }\end{array}$ & 3 & $\mathrm{C}$ \\
\cline { 2 - 4 } & Penyampaianmateri & 5 & $\mathrm{~A}$ \\
\hline \multirow{5}{*}{ Inti } & Menyediakansarana yang dibutuhkan & 4 & $\mathrm{~B}$ \\
\cline { 2 - 4 } & $\begin{array}{l}\text { Memintamasing- } \\
\text { masingsiswabekerjasesuailembarkerja }\end{array}$ & 4 & $\mathrm{~B}$ \\
\cline { 2 - 4 } & $\begin{array}{l}\text { Membimbingdanmengarahkandalammenger } \\
\text { jakansoal }\end{array}$ & 5 & $\mathrm{~A}$ \\
\cline { 2 - 4 } & Membantukelancarankegiatanpembelajaran & 4 & $\mathrm{~B}$ \\
\hline \multirow{2}{*}{ Akhir } & Melakukanevaluasi & 4 & $\mathrm{~B}$ \\
\cline { 2 - 4 } & Mengakhiripembelajaran & 4 & $\mathrm{~B}$ \\
\hline
\end{tabular}

Berdasarkan tabel di atas, ada beberapa hal yang tidak sempat dilakukan oleh peneliti. Namun secara umun kegiatan peneliti sudah sesuai dengan rencana yang telah ditetapkan. Skor yang diperoleh dari pengamatan tentang aktivitas guru adalah 42, sedangkan skor maksimal adalah 50. Sehingga skor yang diperoleh rata-rata adalah $\frac{42}{50} \times 100 \%=84 \%$.

Sesuai taraf keberhasilan yang ditetapkan yaitu:

\begin{tabular}{|c|c|c|c|}
\hline Tingkat Penguasaan & NilaiHuruf & Bobot & Predikat \\
\hline $86-100 \%$ & A & 4 & SangatBaik \\
\hline $76-85 \%$ & B & 3 & Baik \\
\hline $60-75 \%$ & C & 2 & Cukup \\
\hline $55-59 \%$ & D & 1 & Kurang \\
\hline$\leq 54 \%$ & E & 0 & KurangSekali \\
\hline
\end{tabular}

Berdasarkan atas ketetapan pada tabel di atas, maka taraf keberhasilan aktivitas peneliti berada pada kategori baik.

Sementara itu, hasil pengamatan yang dilakukan oleh pengamat kedua terhadap semua aktivitas siswa selama kegiatan pembelajaran berlangsung dapat digambarkan dalam tabel sebagai berikut: 
Tabel 3

Hasil Pengamatan Aktivitas Siswa pada Siklus I

\begin{tabular}{|c|l|c|c|}
\hline \multirow{3}{*}{ Tahap } & \multicolumn{1}{|c|}{ Indikator } & \multicolumn{2}{|c|}{$\begin{array}{c}\text { HasilPengamat } \\
\text { an }\end{array}$} \\
\cline { 3 - 4 } & & Skor & Catatan \\
\hline \multirow{5}{*}{ Awal } & Melakukanaktivitasproses pembelajaran sehari-hari & 3 & C \\
\cline { 2 - 4 } & Memperhatikantujuan & 3 & C \\
\cline { 2 - 4 } & $\begin{array}{l}\text { Keterlibatandalampembangkitanpengetahuansiswatenta } \\
\text { ngmateri }\end{array}$ & 4 & B \\
\hline \multirow{5}{*}{ Inti } & Mendengarkanpenjelasanmateridari guru & 4 & B \\
\cline { 2 - 4 } & Memanfaatkan saran yang tersedia & 4 & B \\
\cline { 2 - 5 } & Mengerjakanlembarkerja & 3 & C \\
\cline { 2 - 5 } & Presentasi & 2 & D \\
\cline { 2 - 5 } & Pembahasan & 4 & B \\
\hline \multirow{2}{*}{ Akhir } & Menanggapievaluasi & & B \\
\cline { 2 - 5 } & Mengakhiripembelajaran & 36 \\
\hline
\end{tabular}

Berdasarkan tabel di atas, dapat dilihat bahwa secara umum kegiatan siswa belum sesuai harapan karena masih banyak descriptor yang tidak muncul dalam aktivitas siswa selama pembelajaran. Skor yang diperoleh tentang aktivitas siswa adalah 36, sedangkan skor maksimal adalah 50 . Sehingga skor yang diperoleh rata-rata adalah:

$$
\frac{36}{50} \mathrm{x} 100 \%=72 \%
$$

Sesuai taraf keberhasilan yang telah ditetapkan maka taraf keberhasilan aktivitas siswa berada pada kategori baik atau tinggi.

\section{b. Hasil Catatan Lapangan}

Hal-hal yang sempat dicatat peneliti dan dua pengamat adalah sebagai berikut:

1. Pada waktu pembelajaran dimulai, masih terdapat beberapa siswa yang ribut dan ramai berbicara dengan temannya serta tidak menghiraukan penjelasan guru sehingga peneliti harus lebih memperhatikan pengelolaan kelas

2. Masih banyak peserta didik yang masih mengandalkan jawaban temannya dan ada juga yang memilih untuk bergabung dengan 
kelompok lain yang dianggap mempunyai kesesuaian dalam bentuk ide atau sikap

3. Beberapa peserta didik lebih senang langsung bertanya kepada peneliti atau guru dari pada berdiskusi dengan temannya yang berada dalam kelompok mereka

4. Banyak peserta didik yang menggunakan media sebagai bahan pajangan saja, tidak untuk menyelesaikan soal-soal evaluasi

5. Beberapa peserta didik terlihat kurang siap dan tegang saat proses pembelajaran karena siswa perlu beradaptasi terlebih dahulu dengan metode dan pendekatan pembelajaran yang diuji coba.

\section{c. Hasil Test peserta didik}

Berdasarkan hasil test akhir siklus I menunjukkan bahwa hasil test siswa tergolong kategori yang berkriteria cukup baik. Apabila dibandingkan dengan hasil test awal dan siklus I ini, maka terjadi peningkatan pemahaman pada siswa. Hal ini dibuktikan dengan nilai rata-rata pre test adalah 70,40 sedangkan nilai rata-rata skor test akhir siklus I sebanyak 85,80. Siswa yang berada pada tingkat kategori tuntas pada penilaian test awal sebanyak 3 atau $22 \%$ orang siswa dan 22 atau $88 \%$ orang siswa yang dalam kategori tidak tuntas. Pada pelaksanaan siklus I terjadi peningkatan yang signifikan yaitu terdapat 22 atau $88 \%$ orang siswa yang tergolong kategori tuntas dan 3 atau $22 \%$ orang siswa yang tidak tuntas.

\section{d. Refleksi}

Berdasarkan kegiatan analisis dan diskusi dengan teman sejawat terhadap hasil test akhir dan hasil pengamatan pada siklus I, maka dapat diperoleh beberapa hal sebagai berikut:

1. Hasil belajar siswa berdasarkan nilai test kelompok menunjukkan nilai yang sangat baik. Namun demikian, dalam mengerjakan soal ujian, siswa masih mengandalkan jawaban dari teman kelompok mereka sehingga ketika mengerjakan soal individu masih terdapat banyak siswa yang mendapatkan nilai di bawah rata-rata.

2. Hasil belajar siswa berdasarkan nilai test akhir siklus I menunjukkan peningkatan yang signifikan dan baik. Hal ini menunjukkan bahwa pemahaman siswa terhadap materi pelajaran semakin meningkat.

3. Aktivitas siswa telah menunjukkan tingkat keberhasilan pada kriteria cukup. 
4. Kegiatan pembelajaran menunjukkan penggunaan waktu yang sudah sesuai rencana, namun masih diperlukan untuk mengatur waktu sehingga dapat dilanjutkan pada siklus II.

5. Siklus II masih perlu dilakukan karena rata-rata skor belum mencapai target standar KKM. Target siswa tuntas pada penelitian ini adalah 75\%. Demikian pula dalam proses pembelajaran secara kelompok diketahui masih terdapat banyak siswa yang bekerja tidak maksimal. Banyak yang gaduh sendiri dan mengandalkan hasil jawaban teman kelompok mereka. Hal ini dikarenakan siswa belum bisa beradaptasi dengan model pembelajaran Student Team Achievment Devision yang digunakan oleh peneliti. Jadi jelas perlu dilakukan siklus II untuk meningkatkan aktivitas dan hasil belajar siswa yang lebih sempurna.

\section{Paparan Data Pelaksanaan Tindakan Siklus II}

\section{a. Aktivitas Guru dan Siswa}

Skor yang diperoleh dari pengamatan tentang aktivitas guru adalah 48, sedangkan skor maksimal adalah 50. Sehingga nilai yang diperoleh rata-rata adalah:

$\frac{48}{50} \times 100 \%=96 \%$. Sesuai taraf keberhasilan yang ditetapkan, maka taraf keberhasilan aktivitas peneliti (guru) berada pada kategori sangat baik.

Hasil pengamatan yang dilakukan oleh pengamat kedua terhadap aktivitas siswa selama kegiatan pembelajaran dapat menunjukkan adanya peningkatan dari pelaksanaan siklus I. Skor yang diperoleh dari pengamat aktivitas siswa sebanyak 48 point, sedangkan skor maksimal dari semua indikator aktivitas siswa tersebut sebanyak 50 point.

$$
\text { Nilai }=\frac{48}{50} \times 100 \%=96 \% \text {. }
$$

Sesuai dengan taraf keberhasilan yang telah ditetapkan maka taraf keberhasilan aktivitas siswa berada pada kategori sangat baik.

\section{b. Hasil Tes Siswa}

Hasil test akhir siklus II menunjukkan bahwa hasil test siswa berkriteria sangat baik, hal ini menunjukkan bahwa terjadi peningkatan pemahaman pada siswa serta terjadi peningkatan hasil belajar yaitu nilai rata-rata siklus II adalah 95,60. Sedangkan nilai rata-rata test siklus I adalah 85,80. Pada siklus II ada 25 siswa yang tuntas belajar dari 25 orang siswa. 
Apabila dibandingkan dengan hasil test siklus I dan siklus II, maka terjadi peningkatan pemahaman pada siswa sebamyak 9,80 point. Hal ini dibuktikan dengan nilai rata-rata test siklus I adalah 85,80 sedangkan nilai rata-rata skor test akhir siklus II sebanyak 95,60. Siswa yang berada pada tingkat kategori tuntas pada penilaian test siklus I sebanyak 22 atau $80 \%$ orang siswa dan 3 orang siswa atau $22 \%$ orang siswa yang dalam kategori tidak tuntas. Pada pelaksanaan siklus II terjadi peningkatan yang signifikan yaitu terdapat 25 atau $100 \%$ orang siswa yang tergolong kategori tuntas dan 0 orang siswa yang tidak tuntas.

\section{c. Refleksi}

Berdasarkan tahapan pelaksanaan kegiatan analisis data dan diskusi dengan teman sejawat terhadap hasil test akhir dan hasil pengamatan/ observasi pada siklus II, maka dapat diperoleh ketetapan penemuan sebagai berikut:

1. Hasil belajar siswa berdasarkan nilai test akhir tindakan menunjukkan peningkatan yang sangat baik dan sangat signifikan dibandingkan dari test awal dan test siklus I sebelumnya. Hal ini menunjukkan bahwa pemahaman siswa terhadap materi pembelajaran semakin menunjukkan terjadinya peningkatan yang signifikan.

2. Siswa menunjukkan dapat bekerja dengan baik dan sungguh-sungguh termotivasi serta dapat menyelesaikan soal secara mandiri tanpa menggantungkan jawaban kepada teman-teman mereka. Oleh karena itu, tidak perlu mengulang dan melanjutkan siklus untuk meningkatkan hasil belajar mereka.

3. Aktivitas guru dan siswa telah menunjukkan tingkat keberhasilan pada kriteria sangat baik. Siswa dapat menunjukkan saling beradaptasi dengan teman mereka, berdiskusi dengan peneliti, dan dapat menikmati metode dan pendekatan model pembelajaran Student Team Achievment Devision. Dengan demikian, tidak perlu dilakukan pengulangan siklus terhadap pelaksanaan aktivitas guru (peneliti) dan siswa.

4. Dalam kegiatan proses pembelajaran menunjukkan penggunaan waktu yang sesuai dengan tahapan perencanaan yang telah ditetapkan sebelumnya.

Berdasarkan hasil refleksi dapat disimpulkan bahwa setelah dilakukan pelaksanaan tindakan pada siklus II ini tidak diperlukan pengulangan siklus 
karena secara umum kegiatan proses pembelajaran telah berjalan sesuai dengan tahapan-tahapan perencanaan. Siswa telah memahami materi pelajaran secara tuntas yang dapat dibuktikan dari perolehan nilai ketuntasan belajar dari $80 \%-100 \%$.

\section{SIMPULAN}

Berdasarkan hasil penelitian tindakan kelas yang dilakukan di kelas XI SMK Negeri 1 Parepare, dapat disimpulkan:

1. Model pembelajaran Student Teams Achievement Divisions memiliki dampak positif terhadap kerjasama antar siswa karena tidak membeda-bedakan dengan yang lain, hal ini ditunjukkan adanya tanggung jawab dalam kelompok dimana siswa yang lebih mampu mengajari temannya yang kurang mampu. Dalam proses pembelajaran dengan menggunakan model pembelajaran Student Teams Achievement Divisions yang dilakukan secara bersiklus, keaktifan siswa mengalami peningkatan yang lebih baik dibandingkan menggunakan metode ceramah.

2. Hasil belajar Pendidikan Agama Islam siswa mengalami peningkatan setelah menggunakan model pembelajaran Student Teams Achievement Divisions. Hal ini dapat ditunjukkan dari nilai rata-rata test siswa, yaitu rata-rata nilai test awal 70,4; pada siklus I nilai rata-rata test akhir tindakan meningkat menjadi 85,80; dan pada test akhir siklus II nilai rata-ratanya meningkat menjadi 96,60. Dengan demikian, model pembelajaran Student Teams Achievement Divisions efektif dalam meningkatkan hasil belajar siswa khususnya di kelas XI SMK Negeri 1 Parepare.

\section{DAFTAR PUSTAKA}

Arends, Richard I. 2008. Learning to Teach: BelajaruntukMengajar.Cet. I; Ed. VII; Yokyakarta: PustakaPelajar.

Chaplin, 2001. KamusLengkapPsikologi, Jakarta: Raja GrafindoPersada.

Cahyo, Agus N., 2013. Panduan Aplikasi Teori-Teori Belajar Mengajar Teraktual dan Terpopuler, Jogyakarta: DIVA Press.

Dalyono, 2005. Psikologi Pendidikan, Jakarta: Rineka Cipta.

Danim, Sudarwan, 2010. Agenda Pembaharuan Sistem Pendidikan, Yokyakarta: Pustaka Pelajar. 
DepartemenPendidikanNasionalRI.,Undang-Undang SISDIKNAS 2003, UU RI.No. 20 Th. 2003.

Echols, John M. dan Hassan Shadily. 2000. KamusInggris Indonesia.Cet. XXIV; Jakarta: PT. Gramedia.

Hidayat. 1986. Teori Efektivitas Dalam Kinerja Karyawan. Yogyakarta: Gajah Mada University Press.

Ismail SM., 2009. Strategi Pembelajaran Agama Islam Berbasis Paikem, Jakarta: Rineka Cipta.

Ngalimun, 2013. Strategi dan Model Pembelajaran, Yogyakarta: Aswaja Pressindo.

Miftahul Huda, 2011. Cooperative Learning, Yogyakarta: PustakaBelajar.

Mulyasa, 2000. Manajemen Berbasis Sekolah, Bandung: Rosdakarya.

Mustamin, Strategi Pembelajaran, Ed. I; Surabaya: Revka Petra Media: 2009.

Rusman, 2012. Model-model Pembelajaran Membangun Profesionalisme Guru, Jakarta: Raja Grafindo Persada.,

Slavin Robert E., 2009. Cooperative Learning Teori, Riset, dan Praktik, Penterjemah: Lita, Bandung: Nusa Media.

Sukardi, Ismail, 2013. Model-Model Pembelajaran Modern: Bekal Untuk Guru Profesinal, Jakarta: Tunas Gemilang Press.

Trianto, 2012. Mendesign Model Pembelajaran Inovatif-Progresif, Jakarta: Kencana. 